\title{
Transformation of Civic Engagement in Society 5.0: Civic Education Socio-Cultural Domain
}

\author{
Anggi Yoga Pramanda*, Moh Muchtarom, Rusnaini \\ Civic Education Postgraduate Program, Universitas Sebelas Maret, Surakarta, Jawa Tengah, Indonesia
}

Received January 17, 2021; Revised February 18, 2021; Accepted March 22, 2021

\section{Cite This Paper in the following Citation Styles}

(a): [1] Anggi Yoga Pramanda, Moh Muchtarom, Rusnaini, "Transformation of Civic Engagement in Society 5.0: Civic Education Socio-Cultural Domain," Universal Journal of Educational Research, Vol. 9, No. 3, pp. 665 - 674, 2021. DOI: 10.13189/ujer.2021.090326.

(b): Anggi Yoga Pramanda, Moh Muchtarom, Rusnaini (2021). Transformation of Civic Engagement in Society 5.0: Civic Education Socio-Cultural Domain. Universal Journal of Educational Research, 9(3), 665 - 674. DOI: 10.13189/ujer.2021.090326.

Copyright $(2021$ by authors, all rights reserved. Authors agree that this article remains permanently open access under the terms of the Creative Commons Attribution License 4.0 International License

\begin{abstract}
The development of information technology which continues to offer a variety of practicalities for activities in everyday life will change the way people view and live in this modern era. Based on the emergence of the phenomena described above, researchers are interested in conducting research related to the transformation of civic engagement by using case studies of the realities of the people of Kampung Taman, Patehan, Kraton, Yogyakarta. This research wants to know the reality that exists through the experience story that exists between the user and technology so that it can be involved in how the involvement of relationships and public awareness results in a social transformation process in the reality of a cyber society. The method used in this research is descriptive qualitative analysis with data collection through interviews, observation and literature study. The results showed that the Kampung Cyber Program refers to actions to solve problems that exist in society and bring change to them. The Kampung Cyber program is an action suitable for the younger generation in carrying out service learning to promote Civic Education and instill civic engagement in the practice of life. This research is a form of Civic Education in the socio-cultural domain that the residents of Kampung Cyber in the existing reality through experience stories that are intertwined between user citizens and technology are online movement, entrepreneurship, volunteerism and economics, resulting in a process of forming civic engagement in the reality of cyber society. The authors found that educational attainment is related to the amount of time that people spend online, and that it is a
\end{abstract}

stronger predictor of internet involvement in non-certainment activities than variables such as race, ethnicity, or income. Controlling for other factors, education, years online, and youth are significantly associated with using the internet to enhance human capital or social capital. These findings are especially relevant to understanding the link between educational competencies and digital citizenship.

Keywords Civic Engagement, Society 5.0, Digital Society, Civic Education

\section{Introduction}

In the era of the Industrial Revolution 4.0, each individual can easily build networks with other individuals without being limited by space and time. The internet, a product of advances in technology and information, has changed the pattern of human social interaction from face to face to community 5.0 mediated by devices. The concept of society 5.0 is not only limited to manufacturing factors but also solves social problems with the help of the integration of physical and virtual spaces [1]. The concept of society 5.0 is an answer to problems with the aim of justice, equity, and common prosperity so as to create a supersmart society [2]. Technology era society 5.0 creates a new value that will eliminate social gaps, age, gender, language and provide products and services that are 
specially tailored to the diverse needs of individuals and the needs of many people.

Cyber society is a term for internet users who actively interact, transact, search for information, or other activities online. The term cybersocial reality is an online life that can be analyzed with a sociological approach regarding its social structure and relations [3]. From Gotved's view, cybersocial can be formed from the participation of individuals or groups who carry out their activities continuously online so as to form patterns, actions and also the meaning of their actions.

The study of the era of the industrial revolution 4.0 which is considered to have the potential to degrade the role of humans gave birth to a concept, namely society 5.0. Through this concept, it is hoped that artificial intelligence will transform big data collected through the internet in all areas of life into a new wisdom, with the hope of increasing human capacity in opening up opportunities for humans. The realization of society 5.0 aims to create a society where it can solve various social challenges by incorporating innovations in the industrial revolution 4.0, thus resulting in the formation of new social capital.

Online interactions can increase social capital be it bonding or bridging. However, there are two contradictory ideas regarding the impact of the internet on the individual social capital of its users. On the one hand, the internet allows individuals to expand their social networks thereby increasing social networks (Facebook which allows one to make friends with thousands of people). But on the other hand, the internet also complements the social environment around it so that the level of social capital ties in the offline environment can be reduced.

Information disclosure from various digital media also provides an opportunity to create a civic engagemnet that is generated through open data. Civic engagement must be formed through two-way communication between the government and its people. Open data plays a role in this context as a way for governments to open up to their citizens. Although open data does not directly connect the government and its people, open data provides information on government data, such as health programs, economic growth, agricultural industry, and so on. Open data, in this case, provides information about the extent to which the government has worked, and how the government is performing.

The widespread use of internet media access in modern society makes people feel more intense about human activities that are mediated by developments in information technology in advancing and developing the potential of society. This encourages residents to create a process of awareness of the importance of internet media in this information age, until now a cyber village has emerged where people in this village have started to be encouraged to continue to follow the global information flow with the help of the presence of ICT, so that people who are in their background experiencing the sophistication of information technology nowadays with the internet media. This cyber village is like a merger between a virtual community and a real community.

The development efforts of residents of Kampung Taman, Patehan, Yogyakarta in supporting the development of ICT and internet media have formed a cyber village where residents are invited to join the cyber community in their daily activities. It can be seen that the reality of Kampung Cyber gives birth to two types of society, namely an open-IT-minded society and an IT-oriented society. An open-IT-minded society has built itself to be closer to the sophistication of ICT. Their thinking has begun to open up to using internet media, but there are also people who in their daily lives have been motivated and oriented to use internet media to facilitate all their activities. In daily use of the internet media will never be separated. It is not only enough to get acquainted with ICT developments, however, it can be implemented in their daily activities. Therefore, it can be concluded that the development of Kampung Cyber can be a pilot project for all villages or villages in various regions who want to develop the community's ability to be literate in IT and internet media, by looking at various socio-biographies of each community character.

The importance of using the internet for all people, so that the role of the internet must be able to have a positive impact on this country and nation, in order to realize digital citizenship. Based on the problems and importance of using the internet above, there is actually an interesting question, how to transform civic engagement from a Kampung cyber into a society 5.0? From the formulation of the problem, it has the aim of knowing the transformation of civic engagement in the cyber village into society 5.0 in realizing digital citizenship.

So efforts are needed to transform the civic engagement of society in the era of Society 5.0, one of which is through the implementation of digital citizenship. Education is a conscious effort carried out by learning activities. Especially in the digital era, like today, education is at the forefront of creating ethical and responsible digital citizens. Establishing digital citizenship can be done through formal education in schools and education in the community. Synergy is needed between the government and community participation to implement digital citizenship education in society, one of which is through the civil society community. In this case, the term civic pertains to individuals as members of society, and civic communities can be conceptualized as places where the form of local social and economic institutional organization facilitates a strong social fabric by densely interweaving citizens together through mostly locally oriented institutions and organizations. So that the community has an important role in society, one of which can be used to build citizens' digital citizenship.

\subsection{Literature Review}

Digital Citizenship as a set of characteristics of a digital 
citizen. Digital citizenship is the ability to participate in society online [19]. Civics subjects as subjects that carry out the task of shaping the character of citizens must guide students to become ethical digital citizens. Isman. et.al suggests that what is meant by digital citizenship is the ability of citizens to use technology competently, understand digital content and be able to assess their credibility, create, research and communicate with the right tools, and think critically about ethical opportunities and challenges in the digital world, make safe, responsible and ethical choices in their use [24].

Therefore, to enter a network society requires knowledge and skills, especially about ethics that must be possessed by every digital citizen. This understanding of digital ethics is expected to be able to bring digital citizens in a more positive direction so that the mission of smart and good citizen is realized. As the vision of Civics Curriculum and Learning in the 21 st century is basically centered on the development of "learning intelligence" in the dimensions of "social, cultural, political, economic, and technological intelligences"[25]. Citizens in the 21st Century are expected to become "Civic Learners" (learning citizens) through developing learning intelligence. Globalization and technological advances cannot be avoided by citizens. So it is necessary to develop technological intelligence from citizens as a handle and understanding for citizens how to live in the era of digital citizenship

\section{Materials and Methods}

This research uses a qualitative approach. Qualitative research is methods for exploring and understanding the meaning that some individuals or groups of people perceive as derived from social or humanitarian problems. The research strategy used in this research is a case study. A case study is a research strategy in which the researcher carefully investigates a program, event, activity, process, or group of individuals. The data used in this research is in the form of descriptive which is a fact finding using the correct interpretation.

Sources of data used in this research are primary data sources that directly provide data to data collectors from various sources such as observation, interviews, and documentation. The research location used for this research is in Kampung Taman RT 36, Kelurahan Patehan, Kraton District, Yogyakarta City.

The reason for choosing in Kampung Taman RT 36, Patehan Village, Kraton District, Yogyakarta City is because it is known as a cyber village and has received visits including from the owner Facebook Mark Zuckerberg, even Minister of Communication and Information, Rudiantara, often visits the cyber village. The cyber village is very strategic because it is in the Yogyakarta Palace area. Kampung Taman RT 36 is indeed located in an urban area that is synonymous with the lives of urban residents and smart cities. However, the experience of Kampung Taman in educating its residents about information technology in the digital era in everyday life is an example of efforts to make smart living dimensions in a smart village that can be developed in rural areas The informants in this study were the initiators of the cyber village and residents in RT 36 / RW 09 Taman Kelurahan Patehan, Kraton District, Yogyakarta City. Determination of research informants was carried out by purposive sampling who were selected with specific considerations and objectives in this study.

The data collection technique is done by using observation, interview, and documentation. Observations in this study were also carried out to obtain an overview of the research subject in carrying out the activities carried out. In the interview data collection technique is used to explore the data needed to answer the problem formulation in research regarding the role of the internet in realizing digital citizenship. Interviews were conducted directly in the sense that the researcher tried to direct the conversation according to the focus of the problem to be solved. Meanwhile, documentation is needed as an effort to support the data that has been obtained through observation and interviews.

After the data collection technique is carried out, the data analysis technique is carried out by selecting data selectively and according to the problems raised in the study. To analyze the data in this study, steps such as data reduction, data presentation, drawing conclusions, and verification are needed base on Miles and Huberman [4]. Data reduction in this study was obtained from data collection techniques in the form of observation, interviews, and documentation, then selected the main data and focused on important things so that the data became clear and systematic. After reduction, the data is presented in a narrative form that describes the research subject in realizing digital citizenship.

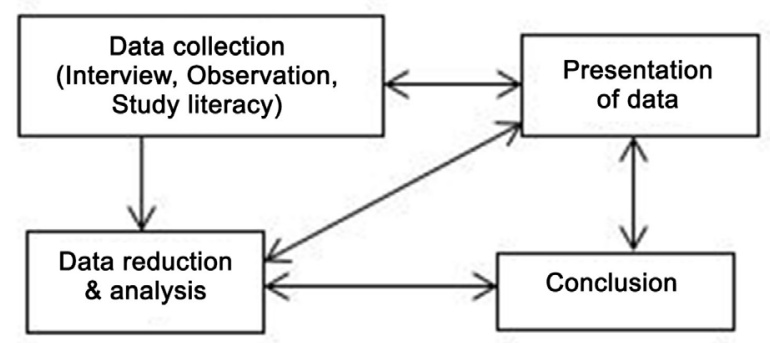

Source: Sugiyono, 2015

Figure 1. The research method

\section{Result and Discussion}

The concept of society 5.0 is an answer to problems with the aim of justice, equity, shared prosperity so as to create a supersmart society [2]. Society era technology 5.0 creates a new value that will eliminate social gaps, age, gender, 
language and provide products and services that are specially tailored to the diverse needs of individuals and the needs of many people.

Era of Society 5.0 is a new era in social life that is centered on humans and based on technology. This concept was born as the development of the 4.0 industrial revolution which is considered to have the potential to degrade the role of humans. Through Society 5.0, artificial intelligence (artificial intelligence) will transform big data collected via the internet in all areas of life into new wisdom, which will be dedicated to enhancing human capabilities in opening up opportunities for human life. This was developed by the Yogyakarta provincial government. Starting in 2006, Yogyakarta province launched the Jogja Cyber Province program as a form of Electronic Government (e-Government) implementation to encourage the use of technology. Electronic Government (e-Government) is an initiative developed to encourage the widest possible use of information and communication technology for the public and government in order to increase interaction with one another. Jogja Cyber Province is a provincial model that transforms community-oriented services based on information and knowledge using information and communication technology as an accelerator for the development of a province that is competitive, comfortable, independent, efficient, and effective. In facing the era of Society 5.0, Yogyakarta Province develops the ability to integrate various resources owned, so that it has connectivity in the mastery of technology, communication and big data to produce 'smart products' and 'smart services', and not just large-scale work productivity.

\subsection{The Process of Externalizing Residents Involve Themselves in the Kampung Cyber Community}

The process of awareness through reflection from the views of others can be defined as "the looking glass self", where self-awareness arises because of the reflection process through social interactions that exist with other individuals who are able to influence us to be similar to himself (another individual) [5]. Through this process of interaction that is able to encourage individuals to participate beyond the reality that has been created in their social environment, so that individuals are motivated to be able to make adjustments to their environment. As expressed by the people of Kampung Taman, who in their social environment have started to recognize and use internet access first.

Individual intellect which is manifested through educational institutions is no longer a big asset, but adequate facilities for life towards modern society are a level point of life [6]. As in the results of this study that some residents provide laptop facilities to each of their children, this is because residents realize that entering the era of information is always superior to the world of IT and internet media. This is in accordance with the theory mentioned by Inkeles in Weiner as the individual's ability to live more advanced is not only determined by the level of knowledge, but adequate facilities to be able to personally develop skills in activities using IT and internet media [6].

Culture is defined not only as a response that has entered human thought, but also as an answer to this response from the human interaction process that involves human patterns to respond to the environment in which humans are present [7]. In connection with the results of this study, some residents do not know how IT and internet media themselves so that when there are social and cultural changes in the scope of their residence, it is this interaction and communication process that encourages them to participate in following these life changes. Human nature is something that is not static,

The strength of subjective knowledge between individuals can differ according to the social biographical situation to carry out direct practice as an important source of user activity in the generative process of information technology. The results of this study indicate that the acquisition of knowledge is not only obtained orally, but the importance of doing practice through training activities on the introduction and understanding of how to use internet media, so that users will give birth to a new culture through ideal understanding and thinking.

\subsection{The Process of Objectivation Residents Involve Themselves in the Kampung Cyber Community}

Objectivation is a social product that occurs in the institutionalized intersubjective reality of society, individuals to manifest themselves into social products that have been created by society in the common world element [8]. Objectification is what leads individuals to realize reality through the thoughts recorded in it. This is as described by Martin and Nakayama in Nasrullah who concluded that interpersonal perceptions and self-concepts provide a new meaning where humans as individuals have a conscious choice to assess the reality they face when interacting with them another individual or community group [9].

Tredinnick, Luke in a digital information culture book states that the basis for balancing the digital divide includes three participant units in culture, namely money, time and education [10]. The output of the gadgets that always appear with the latest versions and specifications has become a high consumptive value. Poindexter [11] which states that members of generation $\mathrm{X}$ are very similar to baby boomers, where generation $\mathrm{X}$ is included in the baby bust generation (aged 1965-1976) in using the internet for entertainment or entertainment needs.

The freedom of informants to choose information from various sources of information available at the website address / links offered in the internet media to make 
knowledge dominate them. This freedom is one of the characteristics of net generation users, as described in Tapscott [11] which states that the first characteristics of net generation are freedom and recruitment. The same is the case with Bakardjieva [12] which states that creative consumers in the use of internet media are consumers (internet clients) who always consider the use of internet media to provide maximum benefits. Young people tend to show identity by creating information in the virtual world using wikis, blogs,

\subsection{The Process of Internalization Residents Involve Themselves in the Kampung Cyber Community}

George Hebert Mest in Santoso [13] which mentions this role as an internalization process, which results in socialization actions to have a dynamic personality because the individual personality will be shaped by the person concerned throughout his life until expressed by the individual in the form of everyday individual behavior.

Development transformation is the existence of continuity and change, so that these two concepts will give birth to new dynamics in community development Citizens' statements regarding technological developments can help Kampung Taman, Patehan, Yogyakarta to get an identity so that they can excel like other villages.

Alch in Sugihartati [11] who examines net generation, in which the study concludes that the need for net generation is to regulate their environment, get information quickly and easily and spend time for themselves. Bakarjieva [12] explains that job uncertainty or dissatisfaction encourages individual aspects to be motivated to use the internet media, to face intellectual challenges and through activities with the internet media is a shortcut to get job information and do potential business.

In the post-industrial era where people will never be separated from the presence of information technology in every aspect of life that can change the pattern of life and lifestyle of people through the internet media. As expressed by residents, the sophistication of information technology and internet networks can change the style and lifestyle of Kampung Taman residents in using e-banking access so that it can be used for all kinds of online-based payments for any need that requires a relationship with IT, such as payment for electricity, telephone, buy credit, online shop, transfer balances, etc. As supported by the statement by Tredinnick, Luke [10] which states that now changes in childhood experiences are influenced by the effect of the development of new media technology.
The formation of a cyber community was preceded by the construction of supporting facilities and infrastructure, namely the internet, which was then followed by community participation in using the internet until finally playing a role as part of the cyber community. The efforts made by the Kampung Taman management towards the cyber village community are to make the village ambassadors in an effort to promote the village through various social media. Thus the pattern given by the village management board would be followed by the village community on the basis of their beliefs. Basically, a social life like the one in Kampung Taman occurs on the basis of innumerable actions and reactions, because it occurs every time people are active. The parties involved in these actions and reactions conform to collective patterns of behavior. Identity as an internet village or cyber village is a collective behavior that the Kampung Taman management tries to instill, which then becomes individual awareness.

The existence of values and norms in Kampung Taman becomes a guideline for social correction when unpleasant actions or actions are performed by the cyber village community through social media. Similar to social deviations that are committed in the real world, deviant behavior that is carried out on social media is also sanctioned based on prevailing values and norms. The existence of values and norms that apply in the use of social media has made the village management community of Kampung Taman more careful in using social media. Some things related to the use of social media are still guarded by the existence of social values and norms, such as the use of foul words, hate speech, are things that can still be controlled by values and norms. As long as the behavior can be seen by group members, the realm of values and norms also applies. But the problem returns to the individual, when individuals misunderstand their actions on social media and society considers them to violate prevailing values and norms. For the people of Kampung Taman, this issue is seen as part of a cultural lag that requires time to adjust.

The relationship that exists between users and technology to informants in Kampung RT 36, Taman, Patehan, Yogyakarta to build awareness by using the internet media can produce typifications of two models that differentiate individuals in their experiences with internet media, which are divided into two models that differentiate individuals in his experience of using internet media, namely open IT-minded and IT-minded orientation. The matrix of the results of this typification can be described in the following table: 
Table 1. Transformation of the Kampung Taman community towards internet media access

\begin{tabular}{|c|c|c|c|}
\hline $\begin{array}{c}\text { Transformation } \\
\text { Process }\end{array}$ & Aspects of Analysis & Open IT-Minded & IT-Minded Orientation \\
\hline \multirow[b]{2}{*}{ Externalizing } & Basic knowledge & $\begin{array}{l}\text { Individuals tend to be passive in } \\
\text { introducing ICT media and do not } \\
\text { have passion }\end{array}$ & $\begin{array}{l}\text { Individual tend to have a passion in the IT field so that } \\
\text { skill about using IT have begun to be embedded in them }\end{array}$ \\
\hline & $\begin{array}{l}\text { Preferences in the } \\
\text { use of internet } \\
\text { media }\end{array}$ & $\begin{array}{l}\text { They tend to adjust to their social } \\
\text { environment in the cyber village, so } \\
\text { they tend to present themselves to } \\
\text { show IT-literate individuals }\end{array}$ & $\begin{array}{l}\text { They tend to look at the interests in the field of work and } \\
\text { education which are able to guide and provide easy } \\
\text { access in the information age, by observing all } \\
\text { dimensions of interest always leading to the world of IT }\end{array}$ \\
\hline \multirow[t]{2}{*}{ Objectivation } & $\begin{array}{l}\text { The implication for } \\
\text { knowledge gained } \\
\text { when experienced } \\
\text { using internet } \\
\text { access }\end{array}$ & $\begin{array}{l}\text { Viewing the internet as a medium } \\
\text { that can provide convenience and } \\
\text { can promote identity / for self-image }\end{array}$ & $\begin{array}{l}\text { Viewing internet media as a medium that can have } \\
\text { positive and negative influences, so that thoughts have } \\
\text { been formed critically in facing various phenomena or } \\
\text { information that they encounter on the internet media. } \\
\text { Individuals are quite selective in receiving all forms of } \\
\text { information and other things }\end{array}$ \\
\hline & Experience gained & $\begin{array}{l}\text { There are not many great benefits } \\
\text { during the experience using the } \\
\text { internet }\end{array}$ & $\begin{array}{l}\text { Get useful experiences in using internet access. Through } \\
\text { his knowledge and abilities, he is able to browse the } \\
\text { internet media according to his needs }\end{array}$ \\
\hline \multirow[t]{2}{*}{ Internalization } & $\begin{array}{l}\text { Ability to face the } \\
\text { times }\end{array}$ & $\begin{array}{l}\text { Using internet access only for } \\
\text { personal gain, is not able to build } \\
\text { awareness or influence others to } \\
\text { become IT literate }\end{array}$ & $\begin{array}{l}\text { Build knowledge and skills for the next generation or } \\
\text { other parties to be able to participate in IT literacy by } \\
\text { providing positive direction and good control } \\
\text { (Reconstructing understanding, knowledge, and ability } \\
\text { in internet media to their social environment for IT } \\
\text { literacy) }\end{array}$ \\
\hline & $\begin{array}{l}\text { Dedication in daily } \\
\text { life }\end{array}$ & $\begin{array}{l}\text { Consumer no creativity, where } \\
\text { individuals only feel what they } \\
\text { consume through the media of the } \\
\text { internet }\end{array}$ & $\begin{array}{l}\text { Consumer creativity, where individuals as internet } \\
\text { media clients not only use it as a medium of } \\
\text { consumption, but through the internet media they are } \\
\text { able to create production }\end{array}$ \\
\hline
\end{tabular}

Source: Processed Data Results, 2020

Proactive action by group members is an important part of the existence of the Kampung Taman community. Proactive action is the attitude of individuals who do not want to stay silent without participating in the group. In this case always looking for ways to be able to participate in the group. The existence of the proactive attitude of Kampung Cyber residents in media management can be seen with various contents that can be found on various social media about Kampung Cyber. Like on YouTube, Facebook, tweeter, or on website pages. At the simplest level, active community participation in media management in Kampung Cyber can be seen from active activities on social media Facebook. For some people in Kampung Cyber Facebook is used as a means of communication to disseminate information related to village activities, especially information aimed at village youth. Various forms of communication carried out through social media by young people in Kampung Cyber contain the spirit of activeness and care in utilizing the functions of social media as they have dreamed of. The active action of the community in using the media in Kampung Cyber is the key to the sustainability of the village as an internet village or cyber village. Society is considered a dynamic process, which is determined by what its members do. Various forms of communication carried out through social media by young people in Kampung Cyber contain a spirit of activeness and care in utilizing the functions of social media as aspired to. The active action of the community in using the media in Kampung Cyber is the key to the sustainability of the village as an internet village or cyber village. Society is considered as a dynamic process, which is determined by what its members do. Various forms of communication carried out through social media by young people in Kampung Cyber contain the spirit of activeness and care in utilizing the functions of social media as they have dreamed of. The active action of the community in using the media in Kampung Cyber is the key to the sustainability of the village as an internet village or cyber village. Society is considered a dynamic process, which is determined by what its members do.

From the discussions conducted, it is known that the existence of the internet in Kampung Cyber has various implications for the social life of the community. Based on the results of observations and data analysis, it is known that there are positive and negative impacts of the internet on people's lives. Forms of positive impacts that can be found with the development of internet networks in Kampung Cyber include: (1) Broad access to information for all residents. The internet installation effort in Kampung Cyber aims to open the widest possible access to information for all residents. The people of Kampung Cyber, who previously experienced backwardness due to being isolated from the outside world, have now become people who are more aware of various information in the world. (2) The population's self-confidence increases. Self-confidence is an effect of being recognized by 
Kampung Cyber on social media and being recognized by various groups ranging from academics to government people. (3) Kampung more widely known as internet village. The existence of the village internet is a characteristic that is pinned to Kampung Cyber.

\subsection{Civic Engagement in the Perspective of Civic Education}

This research took place in Patehan Village, Yogyakarta City, where the main object of study was the Kampung Cyber Program. We can detect that online movement, entrepreneurship, volunteerism and economics are integrated into the Kampung Cyber Program. These matters are supporting civic engagement when referring to Jacoby's opinion again. This includes a wide range of activities, including developing civic sensitivity, participation in building civic society, and benefiting the common good [11]-[13]. On the social side, the Kampung Cyber Program refers to actions to solve problems that exist in society and bring change to them. The Kampung Cyber program is an activity suitable for the younger generation in carrying out service learning to promote Civic Education and instill civic engagement in the practice of life [12].

The aspects of skills developed to equip citizens in the society 5.0 era include civic literacy, global citizenship, digital citizenship. First, civic literacy is focused on the knowledge and abilities of citizens in overcoming problems in social, economic, political and cultural contexts including how to solve social problems.

Second, global citizenship is a series of efforts to prepare citizens to have the ability to communicate and collaborate in relation to interactions between different cultures, sufficient basic knowledge related to aspects of geography, politics, economics, and science and the ability to understand problems and act with knowledge in an interdisciplinary manner and multidisciplinary.

The third aspect is digital citizenship through an understanding of security using the internet, knowing the internet, knowing how to find and create digital content, understanding how to play a role in increasing responsibility in intercultural interactions, and understanding the rights and obligations of using internet media. The third aspect becomes important and more urgent because the internet media is an entry point for applying civic literacy to a global world or global citizenship.

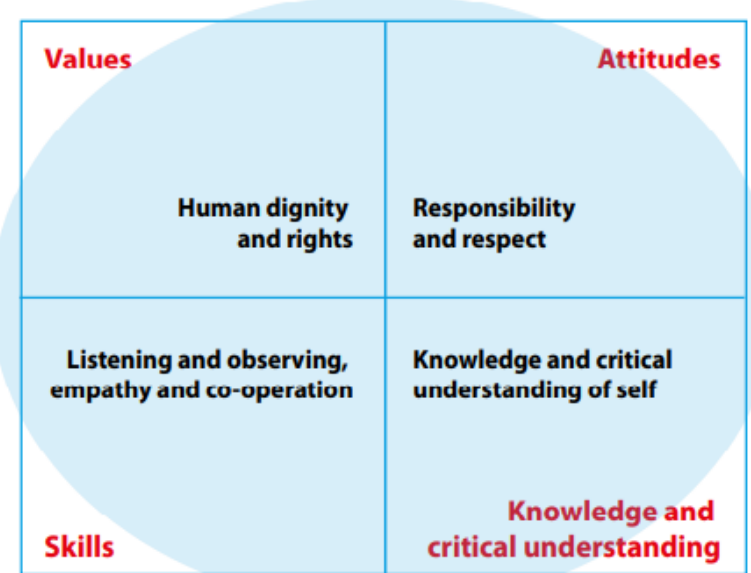

Source : Richardson, Elizabeth Milovidov, 2019

Figur 2. Core digital citizenship competences

Kampung Cyber describes digital literacy efforts and the use of information and communication technology by residents for their daily lives, including improving their economy without intervention from the government or other stakeholders. Digital citizenship is the application of norms for the productive and appropriate use of technology that is relevant to today's technology-rich society and must be an integral part of technology education [17]. Digital citizenship as nine main elements to explain the use of technology in the digital age. These elements are categorized as digital access, digital commerce, digital communication, digital literacy, digital etiquette, digital law, digital rights and responsibilities, digital health and wellness, and digital security [17].

The successful implementation of Kampung Cyber is also due to a good bureaucratic structure. In this case, there is a specialization in the division of tasks and authorities according to the competence that knows cyber problems Kampung Cyber administrators who are very open, responsive, and oriented towards mutual consensus, thus creating good community participation. The establishment of Kampung Cyber was also motivated by complaints, ideas and criticism from the community, especially youth. In addition, it is also inseparable from the direct chain of relationships (chair of demand) without any dividing boundaries between citizens, and levels of government above them, so that when cyber networks encounter obstacles, they can immediately ask for help from those who understand technology. 
Despite the disparities in internet use, there is cause for optimism. The rate at which individuals view political information online has been rising and continues to increase, especially for the young. The impact of digital citizenship is most profound on young people. The young a demographic group with the lowest civic and political participation have the highest probability of seeking online political news and becoming active in politics online. Because the young are more likely to have technology access and use online news [19], the consequences for the sustained engagement of future generations are significant.

This part revealed important evidence (measured with an interaction term) that online news may be especially beneficial for the young, related to increased political sophistication among this age group, and perhaps more permanent changes in civic engagement for the future. Civic engagement provides a foundation for participation, based on an attachment to the political community, as envisioned by civic republicans. The next chapter addresses different forms of political communication on the internet, to find out whether or how they can translate civic engagement into political participation.

Building digital citizenship, Civic Education emphasizes the development of citizens to have the attitude and willingness to interact with fellow citizens both in the community and cyberspace by always maintaining human dignity by having an attitude of sympathy and respect. Respect here is defined as a person's ability to be able to protect himself so as not to harm others. Civic Education learning in schools and colleges emphasizes the theoretical aspects of citizens and government as well as the relationship between citizens and citizens and citizens to the government. However, along with its development, there was an expansion of the meaning of Civics that went beyond the government mechanism by incorporating public welfare into it. Considering that the coverage of Citizenship Education is not only in school, but also exists and must live in the community (socio-cultural). Kampung Cyber program has the potential to be a good tool for civic education and to cultivate it in the civic engagement aspect. Kampung Cyber platform can add real understanding, with knowledge based on actual conditions in the field and then proceed with the hope that it can answer community needs, and involve collaboration between the community and the campus (school).

Civic Education provides new concepts and paradigms to prepare citizens who have multidimensional citizen characteristics [23]. This multidimensional citizen has five main characteristics, namely: "... a sense of identity; the enjoyment of certain rights; the fulfillment of the corresponding obligation; a degree of interest and involvement in public affairs; and an acceptance of basic societal values "[23]. In other words, conceptually Civic Education has the task of building five main characteristics possessed by citizens, namely: have an identity, freedom to obtain certain rights, fulfillment related to obligations, interest and involvement in public affairs, and ownership of basic social values is where one of the roles of Civic Education in developing awareness of citizen interaction this research departs from the opinion of Winataputra, that Civic Education is a scientific structure that has a systemic paradigm in which there are three domains [10]. First, the academic domain, which is a scientific study program conducted by the Civic Education academic community using an approach and scientific research methods for solving conceptual and operational problems. Second, the curricular domain, where the concept and practice of Civic Education in the world of formal and non-formal education. Third, the socio-cultural domain, the concept and praxis of Citizenship Education as a vehicle for the self-actualization of citizens in society. All three have structural and functional interrelationships that are bound by civic virtue and civic culture which includes civic knowledge, civic disposition, civic skills, civic confidence, civic commitment, and civic competence.

Civic Education as a socio-cultural domain is a civic movement that acts as a vehicle for the self-actualization of citizens both individually and in groups according to their rights, obligations and socio-cultural context through active and responsible participation. The socio-cultural civic movement itself is built on the basis of the existence of social institutions based on a system of values and norms, so that society and community in this case need to eliminate public space, so Kampung Cyber as a subject in this study is one form of actualization of the socio-cultural civic movement, which provides space for RT.36 residents to study together to help create society 5.0 , namely people who use the sophistication of information technology in overcoming all daily activities. Kampung Cyber is here to accompany RT.36 residents through the active participation of its members and volunteers in a smart and responsible manner to provide community education through the implementation of technology in community interaction coupled with the cultivation of local wisdom values.

The civic engagement of the citizens of Kampung Cyber when viewed from the Republican Citizenship theory, republican citizenship emphasizes civic bonds which are different from individual bonds (liberal tradition) or group ties (communitarian tradition) [25]. While liberal citizenship emphasizes rights, republican citizenship emphasizes the obligations of citizens. In republican citizenship, individual freedom lies in the guarantee of state security which is under the rule of law and the kindness of these citizens in giving participation. So from the republican tradition, citizenship has ethical and legal dimensions. The legal status of each citizen is closely related to the ownership of privileges regarding rights and obligations towards the common interest or the public interest. Therefore, republican citizenship requires an active commitment in public affairs.

The communication process with residents is carried out 
through village deliberation media in a language that is easy to understand considering the low human resources of Kampung Cyber residents, so that from this process the residents understand the implementation of Kampung Cyber, and can be well received, therefore the residents are very supportive and show enthusiastic attitude [19]. In its development until now, also socialization to the community and personal learning. To expand the transmission of information about the existence of cyber networks and their use, it is formed naturally through the media and routine forums that take place in the community

Meanwhile, the social capital side is the main concern involved in civic engagement, including empathy, ethics and values to focus [14]-[15]. Civic engagement acts on the basis of a high responsibility towards the community that encompasses the idea of citizenship and global interdependence as well as participation in building civil society and empowering individuals as agents of positive social change to promote social justice locally and globally. In developing societies, this social capital becomes an alternative for community development. In fact, society is very communal and they have a lot of values that actually really support the development and strengthening of social capital itself [16]. The reason is social capital provides insight into the meaning of trust, togetherness, tolerance and participation are important pillars of community development as well as pillars for democracy and good governance which are currently being promoted.

\section{Conclusions}

Individuals in their interactions review the dialectical process that creates three social dimensions to form an image in the reality of life, including externalization, objectivation, and internalization. As social beings, in their daily lives, individuals interact and communicate with other individuals, so that in objective actions formed by social construction that are continuously able to build themselves in the dimension of subjectivity. Individuals are able to give meaning to what is done when the individual is constructed subjectively, so that reality is formed in an objective dimension where the individual is able to understand his world which is directly involved in the interaction. The cyber village where the community is technology literate is a reality that exists in Kampung Taman, Patehan, Yogyakarta. The authors found that educational attainment is related to the amount of time that people spend online, and that it is a stronger predictor of internet involvement in non-certainment activities than variables such as race, ethnicity, or income. Controlling for other factors, education, years online, and youth are significantly associated with using the internet to enhance human capital (visiting web sites involving school, work, health, finances, or science) or social capital (visiting sites related to news, government, or politics). These findings are especially relevant with understanding the link between educational competencies and digital citizenship.

\section{REFERENCES}

[1] Skobelev, P \& Borovik, Y S, "On The Way From Industri 4.0 to Industri 5.0 From Digital Manufacturing to Digital Society," International Scientific Research Journal, pp.307-311, 2017.

[2] Fukuyama, F, "Society 5.0: Aiming for a New Human-Centered Society," Japan Special ar, pp. 47-50, 2018.

[3] Gotved, S, "The Construction of Cyber Social Reality. In D. Silver \& A. Massanari. Critical Cyber Cultural Studies," New York: New York University Press, 2006.

[4] Sugiyono, Metode Penelitian Pendidikan (Pendekatan Kuantitatif, Kualitatif, dan R\&D), Bandung: Alfabeta, 2015.

[5] Abdulsyahani, Sosiologi Skematika, Teori dan Terapan, Jakarta: Bumi Aksara, 2007.

[6] Inkeles, A, Modernisasi Manusia in Weiner, Myron Ed, Modernisasi Dinamika Pertumbuhan (Terjemahan), Yogyakarta: Gajah Mada University Press, 2005.

[7] Nasrullah, Rulli, Komunikasi Antar Budaya, Jakarta, Kencana Perdana Media Group, 2012, p. 6.

[8] Bungin, Burhan, Konstruksi Sosial Media Massa, Jakarta, Kencana, 2008, p. 16

[9] Nasrullah, Rulli, Komunikasi Antar Budaya, Jakarta, Kencana Perdana Media Goup, 2012, p. 13.

[10] Tredinnick, Luke, Digital Information Culture: The Individual and Society In The Digital Age, New Delhi: Oxford, 2008.

[11] Sugiharti,Rahma, Perkembangan Masyarakat Informasi dan Teori Sosial Kontemporer, Jakarta: Kencana, 2014.

[12] Bakardjieva, Maria, Internet Society, London: SAGE Publication, 2005.

[13] Santoso, Slamet, Teori-Teori Psikologi Sosial, Bandung: Refika Aditama, 2010.

[14] Rasekhi, A \& Angadji, J S, "The Effect Of Social Participation Of Social Capital Elements On National Unity In Iran," Journal of Currrent Research in Science, Vol.1, pp. $12-21,2014$

[15] Chen, H \& Meng, T, "Bonding, bridging, and linking social capital and self-rated health among Chinese adults: Use of the anchoring vignettes technique," PLOS ONE, Vol.11, pp. $1-15,2015$.

[16] Onyx, J \& Bullen, P, "Measuring social capital in five communities;"Journal of Applied Behavioral Science, Vol.1, pp. $23-42,2000$.

[17] Ribble, Mike \& Bailey, G, "Digital Citizenship In School, Washington DC: International Society for Technology in Education," 2004. 
[18] Jacoby, Barbara \& Associates, Civic Engagement in Higher Education: Concepts and Practices, United States: Jossey-Bass A Wiley Imprint, 2009.

[19] Mossberger, Karen \& Caroline, J Tolbert, Digital Citizenship: The Internet, Society, and Partisipation, Cambride: MIT Press, 2008.

[20] Imandoust, Sadegh Bafandeh, "Relationship between Education and Social Capital.," Journal of Humanities and Social Science, Vol.12, pp.52-57, 2011.

[21] Rusnaini, "Service Learning dalam Komunitas Membangun Civic Resposibility di Indonesia," rev. Seminar Nasional Penguatan Nilai-Nilai Kebangsaan Melalui Pendidikan Kewarganegaraan Persekolahan dan Kemasyarakatan, Surakarta, pp. 3-5, 2018.
[22] Madhavan, E.S, “Internet and social media's social movements leading to new forms of governance and policymaking: cases from India,"Journal of Culture, Politics and Innovation, Vol. 1, pp. 1-32, 2016.

[23] Kartal, Filiz, "Liberal and Republican Conceptualizations of Citizenship: A Theoretical Inquiry,"Turkish Public Administration, Vol. 27-28, pp.101-130, 2016.

[24] Isman, Aytekin , Ozlem Canan Gungoren,Digital Citizenship., TOJET: The Turkish Online Journal of Educational Technology. Vol. 13. 1, p.73, 2014

[25] Winataputra, U. \& Budimansyah, D, Civic Education: Konteks, Landasan, Bahan ajar, dan Kultur Kelas. Bandung: Program Studi Pendidikan Kewarganegaraan SPS UPI, 2012 